\title{
A Collaborative Game
}

The rules of this collaborative game specify that each utterance between the artistic double matthews and allen comprises 140 characters in accordance with the message limit employed by the social media platform Twitter. This absurdist constraint alludes to the act of twittering; short bursts of idle talk.

The reader is invited to 'follow'.

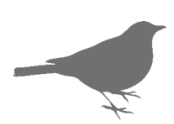

'Most games have a winner and a loser. The basic version of The Collaboration Game is one where the only way to win is for everyone to win.' 1

\section{'Such a game-with neither winner nor loser, without responsibility, a caucus-race, in which skill and chance are no longer distinguishable.' 2}

'They're off! They're off! They're o-off! Backward, forward, outward, inward Bottom to the top Never a beginning There can never be a stop' 3

\section{'Yes, yes, it's the most comical thing in the world. And we laugh, we laugh, with a will, in the beginning. But it's always the same thing.' 4}

'It's a game of course that's what you keep telling yourself.........Bullshit! It's more than that........it's quite serious..........yes!' 5

One day an Englishman, an Irishman, a Scotsman and a Welshman walk into a bar together. The Barman says "What is this, some kind of a joke?" 
'no joke standing joke bad joke joke around take a joke go beyond a joke the joke's on somebody all joking aside you must be joking' 6

'there is nothing more insupportable in society than the everlasting talkers who scatter puns, witticisms, and jokes with so profuse a hand' 7

'without the very performance of chatter there would be nothing to talk about, not even the possibility of talking about the act of talking' 8

'It does sound like idle talk, but listening again I hear interruptions. As each one speaks it sounds as if they are interrupting the other' 9

'without interruption there is no dialogue, if we are in dialogue then we are interrupted, we should be interrupted and we should interrupt' 10

'The Interruption Game. Players: 4 - 10. You play the game twice. The first time with no interruptions, the second time with interruptions.' 11

'The Interruption Game. Players: 4 - 10. You play the game twice. The first time...I'm sorry to interrupt but.. Before we move on may I add?' 12

'One ought to distinguish between two repetitions... they repeat each other, still; they substitute for each other... Nonsense: they are added...' 13 


$\begin{array}{ccr}\text { 'One potato } & \text { Two potatoes } & \text { Three potatoes } \\ \text { Four! } & \text { Five potatoes } & \text { Six potatoes } \\ \text { Seven potatoes More! } & \text { (Repeat)' } 14\end{array}$

'You like potato and I like potahto. You like tomato

and I like tomahto. Potato, potahto, Tomato,

tomahto... laughter... larfter... after... arfter' 15

'this may be as follows: differance always comes before difference(s). We should be careful not to see this simply as wilful or 'playful'.' 16

'words and then other words and then other words in

an infinite process of deferral so that meaning

slides.....in the play of more-than-one' 17

'I've got two. Two what? Two feet ... one more and I'll have a yard. You've got hold of the wrong end of the stick. Oh, let's get on with it.' 18

1 The Collaboration Game, An Over the Edge Experiment in Group Process, Fiscal Policy Studies Institute March 7 , 2002, http://resultsaccountability.com/wp-content/uploads/2014/03/CollaborationGameComplete.pdf, accessed $23^{\text {rd }}$ September 2015

2 Deleuze, Gilles, (2004), The Logic of Sense, London and New York: Continuum International Publishing Group Ltd.: 71

3 The Disney Wiki: The Caucus Race, http://disney.wikia.com/wiki/The_Caucus_Race, accessed $25^{\text {th }}$ September 2015

4 Beckett, Samuel, (2009), Endgame, London: Faber and Faber Ltd.: unpaginated

5 Federman, Raymond, (2008), Double or Nothing, Ullapool: Two Ravens Press Ltd.: 81

6 The Free Dictionary by Farlex, http://idioms.thefreedictionary.com/joke, accessed on $29^{\text {th }}$ September 2015

7 Hartly, Cecil, (2006), Gentlemen's Book of Etiquette, University of Michigan: 12

8 Shepherd, David, Ed., (1998), The Contexts of Bakhtin: Philosophy, Authorship, Aesthetics, Routledge: 202

9 Lomax, Yve, (2004), Sounding the Event, London: I.B.Taurus: 125

10 Nikulin, Dimitri, (2010), Dialectic and Dialogue, Stanford University Press: 104

11. The Interruption Game, http://tastycupcakes.org/2012/08/die-card-die-the-interruption-game/ accessed on $3^{\text {rd }}$ October 2014

12 Etiquette rules to interrupt someone in English, http//learnex.in/etiquette-rules-to-interrupt-someone-in-english/, accessed on $5^{\text {th }}$ October 2015

13 Derrida, Jacques, (2004), Dissemination, London: Continuum: 170

14 One Potato, Two Potatoes, http://supersimplelearning.com/songs/original-series/two/one-potato-two-potatoes/, accessed on $7^{\text {th }}$ October 2015

15 Gershwin, George, \& Gershwin Ira, (1937), Let's Call the Whole Thing Off, (Song)

16 Niall, Lucy, (2004), Derrida Dictionary, Oxford: Blackwell: 1

17 Barker, Chris, (2004), The Sage Dictionary of Cultural Studies, London: Sage Publications Ltd.: 52

18 Bradby, David, (2001), Beckett: Waiting for Godot, Cambridge: Cambridge University Press: 41 